\title{
Complicated High Blood Pressure in Hospital Area in Lomé
}

\author{
Abago Balaka1,2*, Kodjo Agbéko Djagadou1,2, Toyi Tchamdja1,3, Mohaman Awalou Djibril1,2, \\ Findibe Damorou ${ }^{2}$
}

${ }^{1}$ Internal Medecine Unit, Lomé \& Kara, Togo

${ }^{2}$ Health Science Faculty, Université de Lomé, Lomé, Togo

${ }^{3}$ Health Science Faculty, Université de Kara, Kara, Togo

Email: ^francisabago@gmail.com

How to cite this paper: Balaka, A., Djagadou, K.A., Tchamdja, T., Djibril, M.A. and Damorou, F. (2019) Complicated High Blood Pressure in Hospital Area in Lomé. Open Journal of Internal Medicine, 9, 5-11. https://doi.org/10.4236/ojim.2019.92002

Received: April 10, 2019

Accepted: June 24, 2019

Published: June 27, 2019

Copyright $\odot 2019$ by author(s) and Scientific Research Publishing Inc. This work is licensed under the Creative Commons Attribution International License (CC BY 4.0).

http://creativecommons.org/licenses/by/4.0/

\begin{abstract}
The target of the study was to identify patients living with Compound high blood pressure and describe the epidemiological, treatment and progressive aspects. We had realized retrospective and descriptive study completed throughout twelve months from 1st January to December 31, 2011. The study took into account 250 hypertensives known or not admitted in the cardiology and medical intensive care units at the Sylvanus Olympio Teaching Hospital in Lomé. In total, the frequency of complications of the High Blood Pressure was $33.3 \%$ with a male predominance. Patients' average age was 52.4 years. The most frequent reasons of admission were coma (32\%) and hypertensive eruption (28\%). The excessive consumption of salt and alcohol were other dominant modifiable risks factors with respectively $36.8 \%$ and $22.8 \%$. Neurologic complications were the most frequent of cerebrovascular accidents (CVA) (66\%) among which strokes represented $69.7 \%$. Cardiac complications came in second position $(31.2 \%)$. Double treatment was optional in $62.2 \%$ cases with IEC+ Ica++ associated. In $56.6 \%$ cases patients with renal disease in terminal stage had been dialysed. The level of total lethality was $34 \%$. The main cause of death was CVA (cerebrovascular accidents) (85.9\%). High Blood Pressure is then a very plague with regard to its complications. Its effective caretaking is nothing but through primary prevention based on sensitization, education of the entire grass-roots and it requires the mobilization of all social components.
\end{abstract}

\section{Keywords}

High Blood Pressure, Target Organs, Complications, Young Patient

\section{Introduction}

High Blood pressure is defined as the permanent raising of blood pressure supe- 
rior or equal to $140 \mathrm{mmHg}$ for the systolic and or superior or equal to $90 \mathrm{mmHg}$ for systolic [1]. Worldwide, and particularly in developing countries, it is a real public health issue [1] [2] [3]. High Blood pressure affects the whole young population range of 60 years of age and this prevalence increases while getting to $50 \%$ of age with patient of 50 years [4] [5]. Its progress is often speckled with complications of the target organs namely the heart, kidneys, the brain and the eye with unbearable socioeconomic consequences [4] [5]. The appearance of one of its complication is a serious stage in the life of the patient of High Blood pressure followed by the deterioration of life quality and the increasing of caretaking costs. In order to prevent and/or delay its complications' appearance, this study was carried out and targeted to describe the profile of compound High Blood pressure with adults in Togo.

\section{Material and Method}

It was a prospective transversal and descriptive study over twelve months, from $1^{\text {st }}$ January to December 31,2011 . It took place in the cardiology and medical intensive care unit of Sylvanus Olympio Teaching Hospital in Lomé. Included in our study were all Black people, Togolese, of 18 years and over being High Blood pressure patient known or not admitted in both units for a blood pressure superior or equal to $140 / 90 \mathrm{mmHg}$ and presenting at least one complication (Cerebral, cardiac, renal, ocular) confirmed by a para-clinical check-up. Were excluded, persons who don't agree to be included. The data were obtained on a data collection sheet. Parameters studied were: epidemiological data (age, sex, profession), antecedents (personal, family, High Blood pressure prior treatment)clinical data (reason for consultation or referral, delay in symptom progression, the type of High Blood pressure, body mass index), para-clinical data (uremia, serum creatinine, blood glucose, cholesterolemia, triglyceride levels, telemetry, electrocardiography, the back of the eye, cerebral scanner), therapeutic data (Hygienic and dietary measures, antihypertensive drugs, adjuvant treatments) and prognostic data (cardiovascular risk factors, neurological, after-effect deaths). Data were treated and analyzed using Epi software info 6.04.

\section{Results}

\subsection{Epidemiological Aspects}

During our study, 751 High Blood pressure patients were admitted to both services, of which 250 had at least a complication, a frequency of $33.3 \%$. Sex ratio was 1.40 (146 men versus 104 women). The average age was 52.4 years with extremes of 22 and 88 years. Majority of patients were 41 and 50 years old (74 cases) followed by those of 51 and 60 years old (60 cases). Three socio-professional components were the most represented: Housewives (21.6\%), civil servants (20\%) and individuals (18\%) (Table 1).

\section{1) Previous history}

Hundred and seventy-one patients had previous High Blood pressure with a 
Table 1. Distribution of patients according to occupation.

\begin{tabular}{ccc}
\hline & Number & $\%$ \\
\hline Housewives & 54 & 21.6 \\
Civil servants & 50 & 20 \\
Private & 45 & 18 \\
Craftsman & 31 & 12.4 \\
Traders & 29 & 11.6 \\
Retired & 24 & 9.6 \\
Farmers & 15 & 6 \\
Religious & 2 & 0.8 \\
Total & 250 & 100 \\
\hline
\end{tabular}

predominance of those with a High Blood pressure at 1 to 5 years (65.5\%). Among the 171 patients having a previous history of High Blood pressure 110 patients were under anti High Blood pressure treatment (64.3\%) with a bad observance of treatment in $90 \%$ of cases. Concerning family previous history 33 patients (13.2\%) had a hypertensive parent.

The factor of risk of major modifiable cardiovascular found was due to the excessive consumption of salt (36.8\%) (Table 2).

\section{2) Clinical Aspects}

Motives of consultation and admission were: Coma (32\%), High Blood pressure surge (28\%), motor deficit (14.8\%), headache (13.2\%), dyspnoea (11.2\%), others (2\%). The average delay of symptoms progression was 10.03 days with of 1 to 90 extremes.

Average systolic High Blood pressure was 193, 55 with 150 and $300 \mathrm{mmHg}$. Average diastolic High Blood pressure was 111.87 with extremes of 90 and 180 mmHg. Twenty-eight patients have been weighed and 22 patients' heigh was taken. Out of 22 patients 14 were overweight (63.6\%) and 8 were obèse (39.4\%).

\section{3) Complications}

Complications found were: stroke (46\%), cerebral hemorrhgia (20\%), chronic renal failure (7.6\%), Cardiac failure (31.2\%), hypertensive retinopathy (14.8\%) as indicated in Table 3.

\section{4) Treatment Aspects}

All patients enjoyed diabetes hygiene measures including rest, low-salt diet combined with a suitable diet with regard to the existence or not of risk factors.

Sixty-one point two percent (61.2\%) of patients had been put under diuretic combination (Furosémide) and calcic inhibitory (Nicardipine), 12.4\% under diuretic (Furosémide) and enzyme of conservation inhibitory (Captopril most often) as shown in Table 4.

Thirty-seven (37) patients had enjoyed a functional rehabilitation (physiotherapy). Five (5) patients had been dialysed. 
Table 2. Distribution of patients according to modifiable risk factors.

\begin{tabular}{ccc}
\hline & Number & $\%$ \\
\hline Excessive consumption of salt & 92 & 36.8 \\
Consumption of alcohol & 57 & 22.8 \\
Dyslipidemia & 20 & 8 \\
Tobacco & 13 & 5.2 \\
Diabetes & 12 & 4.8 \\
Obeseness & 7 & 2.8 \\
Association of risk factors & 29 & 11.6 \\
Without risk factor & 6 & 2.4 \\
Total & 250 & 100 \\
\hline
\end{tabular}

Table 3. Distribution of patients according to complications.

\begin{tabular}{ccc}
\hline & Number & $\%$ \\
\hline AVCI & 115 & 46 \\
AVCH & 50 & 20 \\
IRC & 19 & 7.6 \\
Cardiac complications & 78 & 31.2 \\
hypertensive retinopathy & 37 & 14.8 \\
Polyvisceral attack & 3 & 1.2 \\
Total & 250 & 100 \\
\hline
\end{tabular}

Table 4. Distribution of patients according to the type of high blood pressure treatment.

\begin{tabular}{ccc}
\hline & Number & $\%$ \\
\hline Diuretic only & 5 & 2 \\
IEC only & 14 & 5.6 \\
Calcium inhibitory & 4 & 1.6 \\
Diurétic + IEC & 31 & 12.4 \\
Diuretic + B-freezing & 3 & 1.2 \\
Diureti + calcium Inhibitory calcic & 153 & 63.2 \\
IEC + calcic Inhibitory & 4 & 1.6 \\
Diurétic + IEC + Inhibitory calcic & 24 & 9.6 \\
Various associations & 12 & 4.8 \\
Total & 250 & 100 \\
\hline
\end{tabular}

\subsection{Progressive Aspects}

Two hundred and forty-five patients (245) were admitted (98\%). During this hospitalization, the progression was favorable in $51.2 \%$ of cases (128 patients) and unfavorable in $48.8 \%$ (122 patients) with 85 deaths, that is an overall mortality level of $34 \%$ and 37 patients with neurological after effects of hemiplegia 
type (14.8\%). The leading causes of death were cardiovascular accident (85.8\%).

\section{Discussion}

\section{1) Epidemiological Aspects}

Hospital frequency of High Blood pressure is variously appreciated by African authors. It varied from $20.83 \%$ to $59.79 \%$ [6] [7] [8] [9]. These observed differences could be explained not only by the number of samples studied, but also by the peculiarity of each study. The most affected range in our study was 41 to 60 years old (53.6\%) as in Mouanodji's set et al. [8] series in Chad. The 35 to 55 age group dominated in the series of Baragou et al., [9] in Togo. Male predominance observed in our sets is similar to other series [8] [9]. However, Diallo et al. [6] had noted a female predominance in her study.

\section{2) Antecedents}

In our set, majority of patients (68.4\%) had a previous history hypertension as reported by other authors [9] [10]. Other cardiovascular risk factors (modifiable) as it happens in the excessive consumption of salt, alcohol, dyslipidemia, tobacco, sedentary lifestyle, diabetes and obesity have also been reported by authors but in various frequencies [10] [11].

\section{3) Clinical Aspects}

Our patients were consulted for the following main reasons: coma (32\%), surge High Blood pressure (28\%), motor deficit (14.8\%), and headache (13.2\%) dyspnea (11.2\%). In their sets, Baragou et al. in 2010 [9] found these same reasons with similar levels, as Mouanodji [8] but at various frequencies.

\section{4) Complications}

Cerebrovascular accidents had been the most predominant complications in our study (66\%), including $46 \%$ of strokes, contraryto Baragou's studies et al., [9] who reported a lower rate. This is serious knowing that this complication is disabling with its socioeconomic consequences. Several studies confirm the prevalence of AVCI compared to AVCH with the hypertensive patients [9] [10] [12].

Hypertensive retinopathy was the third complication in our set (14.8\%). It was objectivized at the back of the eye according to the classification of Keith Wagener and Barker. These abnormalities could be explained by the delay and High Blood pressure caretaking in our milieus.

Chronic renal failure is the fourth complication revealed in our study: 19 cases or $7.6 \%$. 9 patients were in top stage. Indeed, High Blood pressure is an important risk factor which is very frequently manifested during chronic renal failure [13]. We attribute the high percentage chronic renal insufficiency cases to poor caretaking of High Blood pressure (lack of treatment, non-observance of treatment, treatment rupture, and traditional treatment); late consultation and the absence of systematic checkup of each hypertensive patient.

\subsection{Treatment Aspects}

All our patients had enjoyed from hygiene nutritional measures: rest and low 
sodium diet associated with an appropriate diet based on the existence or not of a risk factor. Dual treatment has been predominant in our set (76.4\%) and inhibitory combination of conversion enzyme-calcium was the most used combination (61.2\%). Dual treatment has also been reported by some African authors [14]. The caretaking of complicated High Blood pressure patient would therefore require the combination of several treatment classes.

\subsection{Progressive Aspects}

The progression during admission has been marked by the death of 85 patients or $34 \%$ and the cardiovascular accident mortality was $85.9 \%$ with its prevalence of $(61.6 \%)$ compared to $38.4 \%$ for strokes. The high mortality rates in our developing countries could be explained by the late consultation after the disease. This delay could be related not only to traditional or religious practices, but also to delay in caretaking in our units.

\section{Conclusion}

High blood pressure is a major public health problem. Its gravity is due to its effect on the target organs (brain, heart, eye and kidney) with a clinical symptomatology with high functional signs. This current study allowed us to identify the main complications of this disorder in hospital environment in Lomé. They are dominated by cerebrovascular accident. Strategies put in place for a better primary and secondary prevention of patients at-risk will help to stabilize and/or slow down the progression of this disorder.

\section{Conflicts of Interest}

The authors declare no conflicts of interest regarding the publication of this paper.

\section{References}

[1] Cooper, R., Rotimi, C. and Ataman, S. (1997) The Prevalence of Hypertension in Seven Populations of West African Origin. American Journal of Public Health, 87, 155-156. https://doi.org/10.2105/AJPH.87.2.160

[2] Okonofua, E.C., Culter, N.E., Lackland, D.I. and Egan, B.M. (2005) Ethic Differences in Older Americans Awareness, Knowledge and Beliefs about Hypertension. American Journal of Hypertension, 18, 972-979. https://doi.org/10.1016/j.amjhyper.2005.02.019

[3] Bertrand, E. and Odi-Assomoi, M. (1985) Hypertension artérielle, problème grave de santé publique en Afrique Noire. Sem Hop Paris, 61, 1061-1064.

[4] Safar, M., Safar, H. and Blacher, J. (2007) Physiopathologie de l'hypertension artérielle systolique: Traité de médecine cardiovasculaire du sujet âgé. Edition Flammarion, Paris, 145-151.

[5] Pierre-Guillaume, C., Miget, P., Aubry, C., Gueguen, R., Steyer, E. and Benetos, A. (2006) Contrôle de la pression artérielle par le traitement antihypertenseur chez le sujet âgé de 60 ans. La Revue de Médecine Interne, 27, 285-290. https://doi.org/10.1016/j.revmed.2006.01.004 
[6] Diallo, B.A. (1994) Profil épidémiologique de l'HTA en milieu hospitalier à Bamako. Médecine d' Afrique Noire, 41, 103-105.

[7] N’tyonga-Pono, M.P. (1996) Hypertension artérielle chez le gabonais. Médecine d' Afrique Noire, 43, 434-437.

[8] Mouanodji, M. (1996) Aspects épidémiologiques, cliniques et évolutifs de l'HTA en milieu hospitalier à Ndjamena à propos de 118 cas. Médecine d'Afrique Noire, 43, 580-584.

[9] Baragou, R., Damorou, F., Afangnon, K., Goeh-Akue, E. and Soussou, B. (1998) Les HTA sévères et malignes à la clinique cardiologique du CHU campus de Lomé. Médecine d' Afrique Noire, 45, 587-591.

[10] Chibane, A. (2001) HTA et accidents vasculaires cérébraux. Médecine du Maghreb, 92, 21-23.

[11] Pessinaba, S., Yayehd, K., Pio, M., Baragou, R., Afassinou, Y., et al. (2012) L'obésité en consultation cardiologique à Lomé: Prévalence et facteurs de risque associés: Etude chez 1200 patients. Pan African Medical Journal, 12, 99.

[12] Damorou, F., Togbossi, F., Pessinaba, Y., Klouvi, A., Balogou, A. and Belo, M. (2008) Accidents vasculaires cérébraux et affections cardiovasculaires emboligènes dans les services de cardiologie et neurologique du CHU campus de Lomé. Mali Médical, 23, 31-33.

[13] Mailloux, L. and Levey, A.S. (1998) Hypertension in Patients with Chronic Renal Disease. American Journal of Kidney Diseases, 32, 120-141. https://doi.org/10.1053/ajkd.1998.v32.pm9820471

[14] Youmbissi, T.J., Doumbe, J.M., Ndobo, P. and Kingue, S. (1998) Habitude et hypertension artérielle dans deux grandes villes de Cameroun. Cardiologie Tropicale, 24, 53. 